\title{
Towards a philosophy of teaching physical education in primary school
}

\author{
Janet Currie, University of Technology Sydney (UTS), Australia
}

\begin{abstract}
There has been little research conducted on the philosophy of teaching physical education (PE), with none exploring those specifically held by primary (elementary school) teachers. This is despite the growing trend by teacher education institutions to require that all graduating students develop a portfolio and personal statement of their own philosophy of teaching. Therefore the purpose of this qualitative study was to examine the philosophy of teaching PE as expressed by 54 final-year pre-service primary education students in a written questionnaire. Data analysis followed an inductive approach, whereby categories or dimensions of analysis emerged from the content analysis of the responses to the open-ended question without imposing pre-existing expectations on the research setting or responses. The main themes to emerge from the data focused on the benefits for the child derived from the learning process and the creation by the teacher of a nurturing, engaging and active learning environment.
\end{abstract}

Keywords: Physical Education, Teaching, Philosophy, Pre-Service Teacher

\section{Developing a Philosophy of Teaching Physical Education: Introduction}

A $\mathrm{n}$ expert sports coach or physical education (PE) teacher may be distinguished or differentiated from a novice as being one who exhibits greater experience, expertise, knowledge and skills (Armour 2010; Currie and OatesWilding 2012; Loughran 2010). The best source of professional development or coaching for a beginner teacher is experience in the real world (Dymoke and Harrison 2008). Novice teachers often find experiencing the "real world", such as during teaching practicum, as the most important source of information for improving teaching competence (Cavanagh and Prescott 2015; Schempp, McCullick and Mason 2006). Granted, beginning specialist teachers of physical education in Australia do not normally enter the profession as pure novices. They have often spent years in the sporting domain performing as athletes or coaches, developing an individual "sports literacy" (Pill, Penney and Swabey 2012) and becoming familiar with related responsibilities and approaches. However, generalist primary teachers teach a range of subject areas, with PE just one area to be mastered. Not surprisingly, in primary schools today, teachers can feel daunted with the expectation of delivering regular, safe, fun and engaging PE lessons as part of the national curriculum (Currie 2013).

While teachers have thus been encouraged to update their training and expand their expertise in PE, a great starting point is development of a personal philosophy of teaching. Such reflective processes can include analysis of one's teaching strategies and asking oneself questions such as "What's worth doing?" and "Is what I'm doing working?" (Hellison and Templin 1991). Russell Smelley (2013) indicated that major benefits of articulating a philosophy of teaching are personal development and active consideration appropriate behaviours and approaches to practice. In sports coaching, according to Martens $(2012,5)$ :

Having a well-developed philosophy removes uncertainty about training rules, style of play, discipline, codes of conduct, competitive outlook, short- and long-term objectives, and many other aspects of coaching.

According to Lena Soccorsi $(2013,21)$ a personal teaching and learning philosophy "encompasses what teachers believe and value about teaching, as well as how students learn best". It is also regarded as one of the most important and desirable attributes for development in pre-service teachers (Sheridan and Moore 2009), because it is from this personal philosophy that pre-service teachers will base their professional decisions (Webster 2004). Universities are increasingly requiring graduate pre-service students of teacher education reflect on quality practice and articulate a teaching philosophy as part of a teaching portfolio (CLPDUA 2005, 4; Fung 2006; Lamond 2012), as:

A statement of teaching philosophy allows you to articulate what you believe your role and objectives are as a teacher and what learning objectives you set for your students. The statement should highlight how and why you adopt certain approaches to teaching to achieve these objectives. Typically your statement of teaching philosophy should be a brief statement about your views in relation to your assumptions, attitudes and expectations toward your responsibilities and obligations as a teacher and how this impacts on your approach to teaching. It should highlight what you believe to be your strengths as a teacher (NTEU 2005, 8).

Our teaching practice often rests upon unquestioned beliefs about learning and our philosophy of teaching (Light 2008). While there has been some research conducted on the conceptualisation of reflective teaching (Dewey 1933; Henderson 1988; van Manen 1977), most work has been completed within the discipline of education in general, outside the specific realm of PE. There remains a lack of research conducted into individual philosophy of sports coaching (Jenkins 2010; Martens 2012), with none published exploring the development of one when teaching PE, and none on primary teachers' philosphy in this area. As such, there is no generally accepted "philosophy of teaching physical education". However, for the purpose of this study, Damon Burton and Thomas D. Raedeke $(2008,4)$ articulate a definition of (sports) coaching that may readily translate to PE teaching: 
Your coaching philosophy is a set of beliefs and principles that guide your behaviour. It helps you remain true to your values while handling the hundreds of choices you make as a coach.

Michael Mawer (1999) concluded that to advance knowledge in this area we need to discover more about what teachers themselves are thinking and doing. That is, allow teachers time for reflection and gaining self-awareness of the beliefs, values, principles and assumptions about learning that underpin their behaviour and practices (Cushion 2010). Without an expressed philosophy, especially relating specifically to the teaching of PE, the teacher may lack direction or self-awareness. Therefore the purpose of this study was to explore pre-service primary teachers' expressed philosophy of teaching PE. The next section briefly outlines the method used to access the data.

\section{Method}

Qualitative research was conducted seeking pre-service primary teachers' philosophy of teaching PE. Research participants completed written responses to the simple, open-ended question, 'What is your philosophy of teaching physical education?'. The basic thrust was to minimise the imposition of pre-determined responses and seek depth and detail on what the concept of health meant to the students, a snapshot of their beliefs and thoughts, in their own words and from their own perspectives (Patton, 1980; 1987). A sample of convenience was accessed with 54 fourth year Bachelor of Primary Education university students (mean age $=21$ years) completing a course on physical education for the primary school in the Australian setting completing the questionnaire on the final day of classes.

Data analysis followed an inductive approach, whereby categories or dimensions of analysis emerged from the open-ended question without imposing pre-existing expectations on the research setting or responses (Patton, 1980). Analysis brought order to the data, labelling and organising responses into major themes (Patton, 1987), using the content analysis procedures detailed by Strauss and Corbin (1990). The main themes to emerge from the student responses are those highlighted in the next section.

\section{Findings and Discussion}

\section{Creating a safe and fun learning environment}

The main theme to arise from the data was a teaching philosophy emphasising the creation of a safe and fun learning environment, where students feel safe and wanted to participate. A typical response included:

I want to create a sporting environment that is encouraging, motivating as well as skilful. I want students to be free of fear and want to participate by encouraging them with positive and corrective feedback (Student 27).

Children love to be accepted and feel safe. For primary students to feel positively about taking part in PE, the teacher needs to set and maintain a secure environment with a sense of belonging, acceptance and activities that they can relate to. Alan Launder $(2001,68)$ calls this the 'Protected Learning Environment' where students won't be in fear of being embarrassed or humiliated. This is related to children needing to feel a positive self-concept and self-esteem, both of which contribute to a feeling of individual competence. It is very important that children develop a healthy sense of perceived competence or belief in their ability to capably take part in PE activities. The teaching philosophy in this category characterises inclusive lesson strategies, as described by this respondent:

My philosophy of teaching PE is through teaching inclusive and student-centred physical education so I can have a positive impact on the students for their total wellbeing and enjoyment (Student 21).

\section{Children develop a love of physical activity}

The second major theme to emerge from the data was that from taking part in PE lessons, children develop a love of physical activity. This was to do with adoption of lifelong, healthy lifestyle habits, as explained by these two respondents:

To promote healthy lifestyle behaviours, to provide opportunities for physical activity with an emphasis on enjoyment and participation. To do all of the above in a safe learning space (Student 47).

My philosophy for teaching PE that I would like to develop into my further teaching is that students develop a passion and love for physical activity and living a healthy lifestyle. I will promote this through my teaching by being motivating, prepared, enthusiastic and inclusive. I will put the health and safety of my students first taking into consideration health issues and harmful risks/dangers always (Student 6).

Early childhood experiences are an important determinant affecting lifelong health and wellbeing in a number of ways (Center on the Developing Child at Harvard University 2010). Childhood is an important time for establishing and reinforcing positive health behaviours such as being physically active and consuming a healthy diet, to help prevent 


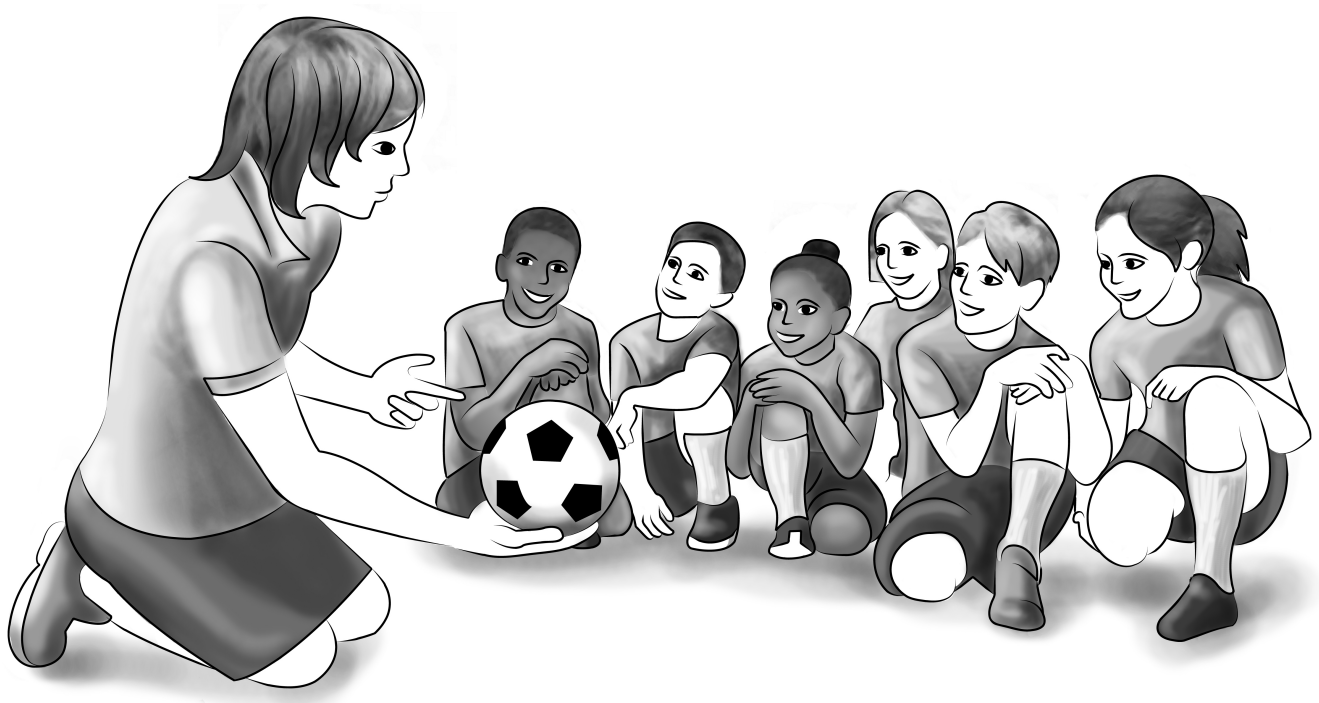

Figure 1: Creating a fun and safe learning environment can include providing frequent, positive feedback (Currie 2013, p.79)

lifestyle diseases such as obesity and dental decay. With incidental exercise among Australian children appears declining and children spending more sedentary time watching television and using computers and video games than recommended by health authorities, PE offers opportunities for movement and the chance to try out and experience games.

\section{Teach an active class with focus on motor skill development}

The respondents articulating this philosophy felt it was important for children to be as active as possible during their PE lessons, and provided with effective skill development opportunities in-class to be able to do this, as exemplified in this response:

Participation is key! Students should understand that 'if you don't try, you won't know'! It's not about who is the most skilled or who has the most experience. Ultimately It's about the growth and achievement throughout the development of a skill. The amount of effort they put into learning and feeling confident executing the skill. Most importantly, don't be scared to be the one making mistakes, because at the end of the day they are gaining the most experience as they develop the understanding of learning from their mistakes. And have fun and enjoy! (Student 30).

These two respondents described a similar approach for their philosophy:

Active participation of all students, inclusion in a fun atmosphere. Respect for one another, adherence to rules and 'learning whilst doing' (Student 31).

My philosophy is to ensure all students are constantly engaged and active, are having a positive and fun experience, whilst in an environment they feel safe and comfortable in (Student 14).

They may have been influenced by recent media reports in Australia regarding the low standard of children's fundamental movement skills (FMS), such as running, jumping, throwing and catching. For example, recent research revealed alarmingly low levels of such motor skills in school children. Findings into a major survey of the fundamental movement skills of 8,000 Australian school children aged five to 16 years found that most seven year olds had not yet mastered leaping, running and jumping. Only about five percent of girls at this age had mastered throwing or kicking a ball. Not even a third of children aged nine and ten years were able to demonstrate that they could run properly (Hardy, Reinten-Reynolds, Espinel, Zask and Okely 2012). According to Lisa Barnett et al. (2013), solutions to address Australian children's lack of mastery in basic FMS include ensuring that all children are given opportunities to be taught FMS during the preschool years; and that primary schools provide a quality HPE program accompanied by appropriate teacher resources and professional development. Adequate FMS are a precursor to children leading active healthy lives.

\section{Holistic development of the child}


Another philosophy was that teaching PE was essentially about attaining holistic development of the child. Responses in this category referred to PE being an opportunity to positively impact on all aspects of the child's health and wellbeing:

Teaching PE is important in primary schools because it positively impacts on the holistic development of the child - promotion of self esteem, mood state, movement skills, fitness and positive social interaction. Teaching PE in primary school benefits the child's overall wellbeing (Student 10).

This includes social, physical as well as mental domains, typified in this response:

To place PE lessons effectively into the schooling curriculum in which they positively impact on the holistic development of the child, developing physical, mental and social characteristics (Student 5).

Primary school-aged children bodies and minds are changing rapidly as they develop physically and mentally. Teachers can implement simple practical strategies such as using modified equipment including softer, larger objects or targets, teach games requiring more cognitive input or ones that involve strategy to score and gain possession, ensure inclusion of all players, rotate players and team members, and include plenty of choice so the child can discover and pursue the activities he or she likes or is 'good at' (Currie 2013). Ensuring provision of daily PE and inclusion of practical living skills on decision-making about nutritional choices or how to incorporating physical activity into one's lifestyle, will help to promote achievement of this philosophy. Counsilman $(2014,15)$ emphasised the athlete-centred (or in this study, a student-centred) approach as a desirable philosophy epitomising maturity in the individual; "The coach must learn to consider the needs of the group before his own, but without totally sacrificing himself and his needs".

\section{PE provides regular opportunities for physical activity}

A similar theme included the notion that participation in regular PE helps to increase physical activity rates in children:

To allow students to participate in meaningful opportunities for movement, sports and exercise, positively impacting on the holistic development of the child (Student 16).

Achterstraat $(2012,26)$ reported that there is a range of barriers to overcome if the quality and quantity of physical activity is to improve in primary schools. According to primary school principals, the two most important barriers needing to be overcome for improving physical activity rates in school are (a) "there are too many other things to do", so a perception of a crowded curriculum or too many things to achieve in a day; and (b) "teachers not skilled and motivated". The two potential solutions to overcome these barriers were to "recruit specialist PE teachers" or "improve access to professional development in PE". While there is a prevailing view amongst teachers and principals that providing greater pre-service and in-service training would increase the competence and confidence of many primary school teachers to enable them to provide quality physical activity to students, the current focus on external testing scores and national reporting provides a strong incentive and distraction to give priority to literacy and numeracy development instead (Achterstraat 2012, 16, 19). This respondent recognised the benefit for PE classes to boost rates of physical activity in children:

I would provide a safe protected learning environment for my students, promote healthy eating whether I am setting an example myself or they learn it through the curriculum and prioritise time so that my students are engaged in as much physical activity as possible during school (Student 53).

\section{Enthusiastic teacher}

This theme related to being an enthusiastic, energetic and encouraging teacher, with effective teaching practices, illustrated by this response:

My philosophy of teaching PE comprises of four key principles. These include: knowing subject content and delivering it appropriately, providing a safe environment, implementing interesting learning experiences, and most importantly maximising active time. These principles are crucial as it allows children to have fun and enjoy participating in PE lessons (Student 44).

When students find activities engaging, motivation, attainment and discipline levels all improve (Morley and Bailey 2009). We need to involve students so they feel greater ownership and control over their learning. Essentially it is up to the teacher to try and engage students by ensuring activities are interesting and that there is as little waiting or potential 'loitering' time as possible! The PE teacher must be enthusiastic, energetic, approachable and fair in his/her actions and approach. Motivation in a class equates to the students being able to experience success at least 80 percent of the time, creating a success-oriented, yet challenging environment. Students should concern themselves with self-improvement and her/his own performance, not to worrying about what others are doing. 


\section{Teacher as a role model}

Comparable to the previous theme was the concept of teacher being a role model for the students. Aiming to be an inspiring role model when teaching physical education is key because if you are passionate about what you do, the students will pick up on this and reflect your enthusiasm. This respondent explained her philosophy influenced her whole approach:

Lead by example - actively promote healthy eating and lifestyle choices to my class everyday, not just during PE lessons! (Student 18).

The teacher can also be an effective role model by setting a good example, for instance by not carrying a can of soft drink around during playground duty or at sports carnivals, or shouting negatively at children when coaching at sports competitions and events. As a positive role model, avoid giving negative feedback. Again, this means focusing on saying what you want the class to do, rather than on what you don't want them to do. Verbal praise is also an effective measure in helping reduce 'off-task' behaviours of students, or goofing off in class.

\section{Using a 'Games Sense' approach}

The final theme to emerge from the data illustrating an espoused teaching philosophy was that of adapting a 'games sense' approach (Thorpe, Bunker and Almond 1986):

I appreciate and will aim to incorporate games sense in to my PE teaching as I appreciate the hands-on, engaging nature. I believe PE should be engaging and active and enjoyable and I feel game sense does this while developing skills (Student 36).

The games sense approach to teaching PE aims to develop mindful, 'thinking' players able to solve problems, who develop greater tactical awareness and an ability to implement strategy for gaining advantage in a real game setting. Lessons feature various activities to develop students' motor competence and skills, undertaken in the context of the real game itself. Bunker and Thorpe (1982) proposed that for effective motor skill learning to occur, practices need to be based within authentic game situations and incorporating the normal requirements of the game (Thorpe and Bunker, 2010). Students get to focus on playing a game instead of mainly technique through isolated skill drills, and simple challenges are attempted leading up to more complex ones. It is also thought that it is more motivating for students as they try out a basic game first up. The teacher can then stop a lesson activity to highlight correct technique, give diagnostic feedback, or add tips to help players have more success, but it also draws out for students the background rationale for positioning, passing choices or other types of strategy to 'win'. This lesson approach is effective as students can see the link between practice or skill development and a real game situation so it is able to produce meaningful, authentic learning.

\section{Pre-service teachers' philosophy of teaching PE: Conclusion}

On invitation, all respondents were able to easily define their philosophy of teaching PE. An interesting feature to arise from the analysis of the data was that the main ideas or themes contained in the respondents' philosophies were in many cases 'overlapping' or inter-related. This might be due to all respondents undertaking the same preparatory PE subjects within the same University program and being delivered the same content to reflect upon. It was noteworthy that their philosophies often focused on the needs of the children taught.

For this group of pre-service primary teachers, articulating a personal philosophy fully reflective of practice was a relatively easy practice, which will become easier over time with greater teaching exposure and experience. It was a worthwhile process for respondents to go through in assisting with development of self-awareness and critical reflection about teaching practice. The statement requires teachers to identify personal strengths and weaknesses, or 'know themselves', and be able to articulate a rationale for 'what they do and why'. International researchers have recognised that the past lived experiences of pre-service teachers when school students plays a significant part in shaping and moulding their understanding of what it is to be a physical education teacher and how teaching should be enacted (Brennan 2006; McNeill et al. 2004; Pill, Penney and Swabey 2012). It is not known how much this influenced the students' responses, however, it is known that one's publicly espoused philosophy might be at odds with actual teaching practice (Jenkins 2010). This study is only a starting point towards an understanding of the philosophy of teaching PE in the primary school and much further research needs to be done. 


\section{REFERENCES}

Achterstraat, Peter. Physical Activity in Government Primary Schools: Department of Education and Communities. New South Wales Auditor-General's Report Performance Audit. Sydney: Audit Office of NSW, 2012.

Armour, Kathleen M. "The learning coach...the learning approach: professional development for sports coach professionals”. In Sports Coaching. Professionalism and Practice, edited by John Lyle and Chris Cushion, 153-65. Edinburgh: Churchill Livingstone, Elsevier, 2010.

Barnett, Lisa M., L. L. Hardy, D. R. Lubans, D. P. Cliff, A. D. Okely, A. P. Hills and P. J. Morgan on behalf of the Physical Activity and Sedentary Behaviour Stream of the Australasian Child and Adolescent Obesity Research Network (ACAORN). "Australian children lack the basic movement skills to be active and healthy." Health Promotion Journal of Australia 24 (2013): 82-4.

Brennan, P. "From rhetoric to reality: A case study of partnerships for improvement." The Bulletin of Physical Education 42 (2006): 16-33.

Bunker, D. and R. Thorpe. "A model for the teaching of games in secondary schools". Bulletin of Physical Education 18 (1982): 5-8.

Burton, Damon and Thomas D. Raedeke, Sport Psychology for coaches. Champaign, IL.: Human Kinetics, 2008.

Cavanagh, Michael and Anne E. Prescott, Your professional experience handbook: a guide for pre-service teachers. Frenchs Forest, NSW: Pearson Australia, 2015.

Center on the Developing Child at Harvard University, The foundations of lifelong health are built in early childhood (2010), accessed October 14, 2015 from

http://developingchild.harvard.edu/resources/reports_and_working_papers/foundations-of-lifelong-health/

Centre for Learning and Professional Development, University of Adelaide (CLPDUA), Developing Your Teaching

Portfolio (2005), accessed September 22, 2015 from https://education.adelaide.edu.au/downloads/teaching-portfolio.pdf

Counsilman, James, E. “The Search for a Philosophy of Coaching”. American Swimming 6 (2014): 12-28.

Currie, Janet L. Teaching Physical Education in Primary School: An integrated health perspective. Camberwell, Vic.: ACER Press, 2013.

Currie, Janet L. and Shelley Oates-Wilding. "Reflections on a dream: Towards an understanding of factors Olympic coaches attribute to their success". Reflective Practice 13 (2012): 425-438.

Cushion, Chris. “Coach behaviour”. In Sports Coaching. Professionalism and Practice, edited by John Lyle and Chris Cushion, 43-62. Edinburgh: Churchill Livingstone, Elsevier, 2010.

Dewey, John. How we think. Chicago: Henry Regnery, 1933.

Dymoke, Sue and Jennifer Harrison. Reflective teaching and learning: a guide to professional issues for beginning second teachers. London: Sage, 2008.

Fung, Yvonne. Portfolio assessment in in-service teacher education programmes, AARE Conference Proceedings (2006), accessed September 21, 2015 from http://www.aare.edu.au/publications-database.php/5038/portfolioassessment-in-in-service-teacher-education-programmes

Hardy, Louise, Tracie Reinten-Reynolds, Paola Espinel, Avigdol Zask and Anthony D. Okely, "Prevalence and Correlates of Low Fundamental Movement Skill Competency in Children". Pediatrics July (2012), accessed September 14, 2015. doi: 10.1542/peds.2012-0345, http://pediatrics.aappublications.org/content/early/2012/07/18/peds.2012-0345

Hellison, Donald R. and Thomas J. Templin. A Reflective Approach to Teaching Physical Education. Champaign, IL.: Human Kinetics, 1991.

Henderson, James G. "A curriculum response to the knowledge base reform movement". Journal of Teacher Education 39 (1988): 13-7.

Jenkins, Simon. “Coaching philosophy”. In Sports Coaching. Professionalism and Practice, edited by John Lyle and Chris Cushion, 233-42. Edinburgh: Churchill Livingstone, Elsevier, 2010. 
Lamond, Alli. Professional Teaching Standards Portfolio (2012), accessed September 22, 2015 from http://learnonline.canberra.edu.au/portfolio/view/view.php?id=12765

Launder, Alan G. Play Practice. The games approach to teaching and coaching sports. Champaign, IL.: Human Kinetics, 2001.

Light, Richard. "Complex Learning Theory - Its Epistemology and Its Assumptions About Learning: Implications for Physical Education". Journal of Teaching in Physical Education 27 (2008): 21-37.

Loughran, John. What expert teachers do: enhancing professional knowledge for classroom practice. Sydney: Allen \& Unwin, 2010.

Martens, Rainer. Successful Coaching, $4^{\text {th }}$ edn. Champaign, IL.: Human Kinetics, 2012.

Mawer, Michael. "Teaching Styles and Teaching Approaches in PE: Research developments". In Learning \& Teaching in Physical Education, edited by Colin A. Hardy and Michael Mawer, 83-104. London: Taylor \& Francis, 1999.

McNeill, M., J. Fry, S. Wright, W. Tan and T. Rossi. "Understanding time management and questioning strategies used in a games concept approach to develop 'Game Sense'”. Physical Education and Sport Pedagogy, 13 (2008): 231-49.

Morley, D. and R. Bailey, R. Meeting the needs of your most able pupils: Physical Education \& Sport. Oxon, UK: Routledge, 2009.

National Tertiary Education Union National Office, Policy \& Research Unit (NTEU), Preparing and Presenting $a$ Teaching Portfolio (2005), accessed September 22, 2015 from staff.mq.edu.au/public/download.jsp?id=102870

Patton, Michael. Q. Qualitative Evaluation Methods. Beverly Hills: Sage, 1980.

Patton, Michael. Q. How to Use Qualitative Methods in Evaluation. Newbury Park: Sage, 1987.

Pill, Shane, Dawn Penney and Karen Swabey. "Rethinking Sport Teaching in Physical Education: A case study of research Based Innovation in Teacher Education". Australian Journal of Teacher Education 37 (2012): 118-138. Article 8. Accessed 9 September 2015 from http://ro.ecu.edu.au/cgi/viewcontent.cgi?article=1772\&context=ajte

Schempp, Paul G, Bryan McCullick and Illse Sanon Mason. "The development of expert coaching", In The Sports Coach as Educator: Re-conceptualising Sports Coaching, edited by Robyn L. Jones, 145-61. London: Routledge, 2006.

Sheridan, L. and C.L. Moore. "Staff perceptions of desirable "teacher qualities" for pre-service teachers". Paper presented at AARE 2009 International Education Research Conference, University of Canberra, Canberra, 29 November -03 December, 2009.

Smelley, Russell C. “The value of a coaching philosophy”. Track Coach, Summer (2013): 6506-14.

Soccorsi, Lena. "Instilling a personal teaching philosophy in pre-service teachers: Vitally important but not always easy to achieve". Journal of Student Engagement: Education Matters 3 (2013): 21-28.

Strauss, Anselm L. and Corbin, Juliet M. Basics of qualitative research: grounded theory procedures and techniques. Newbury Park, CA: Sage Publications, 1990.

Thorpe, R. and D. Bunker. "Preface" In More teaching games for understanding: Moving globally, edited by J. Butler and L. Griffin, xi-xv. Champaign, IL: Human Kinetics, 2010.

Thorpe, R., D. Bunker and L. Almond. Rethinking games teaching. Loughborough, UK: Loughborough University of Technology, 1986.

van Manen, Max. "Linking Ways of knowing with ways of being practical". Curriculum Enquiry 6 (1977): 205-28.

Webster, R.S. "Doing the ultimate public good through teacher education". Paper presented at AARE 2004 Conference of the Australian Association for Research in Education, Monash University, Melbourne, 28 November-02 December, 2004.

Wooden, John R. "The John R. Wooden Course - Pyramid of Success", 2015. Accessed August 27, 2015 from http://woodencourse.com/woodens_wisdom.html 


\begin{abstract}
ABOUT THE AUTHOR
Janet L. Currie: Dr Janet Currie PhD has been in teacher education for over 25 years and has designed and published numerous educational materials about health promotion and exercise including books, videos, teacher and community resources. A past national level netballer, rower and athlete, Janet enjoys creating effective health education messages designed for engaging students and created the Dream, Believe, Achieve secondary school health education teacher resources for the National Rugby League and Australian high schools, to encourage students to build healthy lifestyles and find positive ways to achieve their dreams. Dr Currie is past National President, Vice-President and State representative of the Australian Health Promotion Association; Director and Chair of Health Education and Promotion International; and Director of the UTS Union Board Ltd. She has also been a group exercise leader for over 30 years, and developed the highly successful Strollers Pramwalking Program for new mothers. Dr Currie joined the School of Education at the UTS in 2008, helping prepare the next generation of primary and secondary teachers in this area.
\end{abstract}

